\title{
Macrofauna communities of the Dogger Bank (central North Sea) in the late 1990s: spatial distribution, species composition and trophic structure
}

Received: 15 April 2002 / Revised: 4 November 2002 / Accepted: 4 November 2002 / Published online: 23 January 2003 C) Springer-Verlag and AWI 2003

\begin{abstract}
Macrofauna samples were taken in May 1996-1998 at 28 stations on the Dogger Bank (central North Sea) to describe species composition, spatial distribution and trophic structure of the macrofaunal communities. In general, five communities could be distinguished depending on the influence of different water masses, depth, type of sediment and food availability. Except for those species which feed in the sediment, macrofauna communities did not show any correlation to the measured sediment variables. In fact, macrofauna communities of the Dogger Bank were mainly structured by lateral food supply via frontal systems. This was indicated by the dominance of interface feeders foraging in the benthic boundary layer, which are able to switch from surface deposit to suspension feeding depending on flow conditions. The importance of sandlickers in the shallowest parts of the Dogger Bank hints at an important contribution of benthic primary production to the nutritional and energetic needs of the benthic community.
\end{abstract}

Keywords Macrofauna communities · Benthos · Trophic structure · Total organic carbon (TOC) · North Sea $\cdot$ Dogger Bank

\section{Introduction}

The North Sea is one of the most intensely studied marine environments of the world, but ecological aspects and interrelationships are still poorly understood. Little is known about the offshore areas of the central and northern North Sea, whereas coastal areas have been investigated very thoroughly. In May 1986 the macrofauna communities of

Communicated by E. Rachor

G. Wieking · I. Kröncke (

Department of Marine Research,

Senckenberg Institute, Schleusenstrasse 39a,

26382 Wilhelmshaven, Germany

e-mail: ingrid.kroencke@ senckenberg.de

Tel.: +49-4421-947532, Fax: +49-4421-947550 the whole North Sea were studied synoptically by the ICES Benthos Ecology Working Group (Heip et al. 1992; Künitzer et al. 1992). According to the results of this North Sea Benthos Survey, the factors structuring species distributions and assemblages seemed to be temperature, the influence of different water masses (e.g. Atlantic water inflow), the type of sediment and the food supply to the benthos (Künitzer et al. 1992). The Dogger Bank proved to be a special region which separates the species and communities of the northern and southern North Sea.

Due to its importance for fisheries in former years, the Dogger Bank has been the subject of intensive investigations since the beginning of the twentieth century. First investigations were carried out by Davis (1923, 1925) in 1921-1924. In 1950-1954 the echinoderm, polychaete and bivalve fauna of the Dogger Bank area were investigated by Ursin (1960), Kirkegaard (1969), and Petersen and Høpner (1977). At approximately the same time, Birkett sampled the western part of the Dogger Bank (cited in Kröncke 1991). The investigations from the first half of the twentieth century concentrated especially on zoogeography and gave only limited information on ecological aspects of the communities as well as on the distribution of other taxonomic groups, e.g. amphipods, due to rather coarse sieves.

During April/May 1985-1987, Ursin's stations were partly revisited by Kröncke $(1990,1991,1992)$. The long-term comparison of the macrofauna communities on the Dogger Bank revealed an increase in opportunistic species and an eightfold increase in biomass. The extensive Spisula and Mactra patches described by Davis (1923, 1925), and to a lesser extend by Petersen and Høpner (1977) and Birkett (cited in Kröncke 1991), had disappeared. The observed changes were suggested to be the result of an increasing eutrophication and pollution of the central North Sea.

Within the framework of a renewed long-term comparison, the stations sampled in the 1980s (Kröncke 1992) were revisited in May 1996-1998. The aim of this paper is to describe the spatial distribution, species composition and trophic structure of macrofaunal com- 
munities of the Dogger Bank in the late 1990s for the better understanding of the long-term changes found by Wieking and Kröncke (2001).

\section{Methods}

\section{Sampling design}

Twenty-eight stations were selected on the Dogger Bank. The water depth ranged from $18 \mathrm{~m}$ at the shallow stations on top of the bank to $68 \mathrm{~m}$ in the deeper southern part and $47 \mathrm{~m}$ in the northern part (Fig. 1, Table 1). Macrofauna samples were taken in May 1996, 1997 and 1998 with RV "Senckenberg". Two samples were taken at each station with a $0.2 \mathrm{~m}^{2}$ van Veen grab, weighing $150 \mathrm{~kg}$. Macrofauna grab samples were washed over $1 \mathrm{~mm}$ mesh size. The retained material was preserved in $4 \%$ buffered formalin.

For analysis of the fine fraction $(<63 \mu \mathrm{m})$, organic carbon and nitrogen contents of sediments, samples were taken from an additional grab and frozen at $-20^{\circ} \mathrm{C}$.

\section{Sample treatment}

\section{Macrofauna}

In the laboratory, macrofauna samples were stained with Bengal Rose prior to sorting. The organisms were sorted, identified to the lowest possible taxon and counted. Species abundance data are standardized to a total per square metre at each site. The species number is given as total number for both samples $\left(0.4 \mathrm{~m}^{2}\right)$.

Species composition, total abundance and species numbers of the different communities are given as mean numbers for May 1996-1998, as the ordination by multidimensional scaling (MDS) performed for the three years showed that communities remained similar throughout the years 1996-1998.

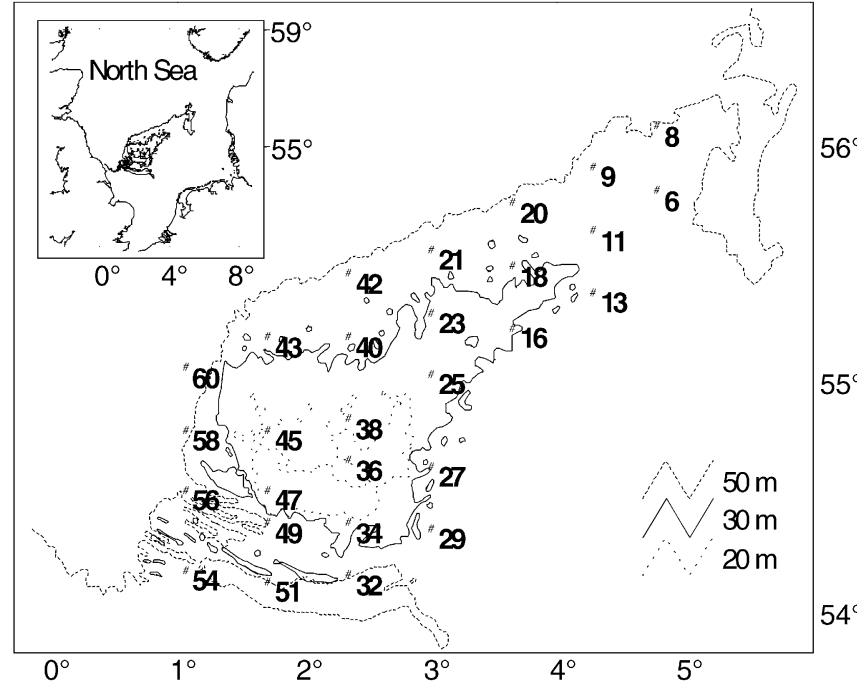

Fig. 1 Map of the area of investigation in the central North Sea with sampling stations

Statistical tests comparing the fauna and sediment parameters were performed with the data from May 1996 and, accordingly, sediment and trophic structure data are given as examples for this year. As recent investigations showed that sediment parameters did not show significant differences throughout the years, these are suggested to be representative.

The general trophic structure of the communities was assigned by classification into feeding types using information from the literature (e.g. Fauchald and Jumars 1979; Lincoln 1979; Hayward
Table 1 Location and depth of the sampling stations as well as dates of sampling

\begin{tabular}{|c|c|c|c|c|c|c|}
\hline \multirow[t]{2}{*}{ Station } & \multirow[t]{2}{*}{$\mathrm{N}$} & \multirow[t]{2}{*}{$\mathrm{E}$} & \multirow[t]{2}{*}{ Depth (m) } & \multicolumn{3}{|c|}{ May } \\
\hline & & & & 96 & 97 & 98 \\
\hline 6 & $55^{\circ} 48^{\prime}$ & $04^{\circ} 51^{\prime}$ & 34 & $\mathrm{x}$ & & $\mathrm{x}$ \\
\hline 8 & $56^{\circ} 04^{\prime}$ & $04^{\circ} 51^{\prime}$ & 43 & $\mathrm{x}$ & $\mathrm{x}$ & $\mathrm{x}$ \\
\hline 9 & $55^{\circ} 54^{\prime}$ & $04^{\circ} 20^{\prime}$ & 43 & $\mathrm{x}$ & $\mathrm{x}$ & $\mathrm{x}$ \\
\hline 11 & $55^{\circ} 38^{\prime}$ & $04^{\circ} 20^{\prime}$ & 32 & $\mathrm{x}$ & $\mathrm{x}$ & $\mathrm{x}$ \\
\hline 13 & $55^{\circ} 22^{\prime}$ & $04^{\circ} 20^{\prime}$ & 42 & $\mathrm{x}$ & $\mathrm{x}$ & $\mathrm{x}$ \\
\hline 16 & $55^{\circ} 13^{\prime}$ & $03^{\circ} 40^{\prime}$ & 32 & $\mathrm{x}$ & $\mathrm{x}$ & $\mathrm{x}$ \\
\hline 18 & $55^{\circ} 29^{\prime}$ & $03^{\circ} 40^{\prime}$ & 31 & $\mathrm{x}$ & $\mathrm{x}$ & $\mathrm{x}$ \\
\hline 20 & $55^{\circ} 45^{\prime}$ & $03^{\circ} 40^{\prime}$ & 47 & $\mathrm{x}$ & $\mathrm{x}$ & $\mathrm{x}$ \\
\hline 21 & $55^{\circ} 33^{\prime}$ & $03^{\circ} 00^{\prime}$ & 40 & $\mathrm{x}$ & $\mathrm{x}$ & $\mathrm{x}$ \\
\hline 23 & $55^{\circ} 17^{\prime}$ & $03^{\circ} 00^{\prime}$ & 29 & $\mathrm{x}$ & $\mathrm{x}$ & $\mathrm{x}$ \\
\hline 25 & $55^{\circ} 01^{\prime}$ & $03^{\circ} 00^{\prime}$ & 23 & $\mathrm{x}$ & $\mathrm{x}$ & $\mathrm{x}$ \\
\hline 27 & $54^{\circ} 37^{\prime}$ & $03^{\circ} 00^{\prime}$ & 33 & $\mathrm{x}$ & $\mathrm{x}$ & $\mathrm{x}$ \\
\hline 29 & $54^{\circ} 21^{\prime}$ & $03^{\circ} 00^{\prime}$ & 39 & $\mathrm{x}$ & $\mathrm{x}$ & $\mathrm{x}$ \\
\hline 32 & $54^{\circ} 09^{\prime}$ & $02^{\circ} 20^{\prime}$ & 51 & $\mathrm{x}$ & $\mathrm{x}$ & $\mathrm{x}$ \\
\hline 34 & $54^{\circ} 23^{\prime}$ & $02^{\circ} 20^{\prime}$ & 27 & $\mathrm{x}$ & $\mathrm{x}$ & $\mathrm{x}$ \\
\hline 36 & $54^{\circ} 39^{\prime}$ & $02^{\circ} 20^{\prime}$ & 18 & $\mathrm{x}$ & $\mathrm{x}$ & $\mathrm{x}$ \\
\hline 38 & $54^{\circ} 50^{\prime}$ & $02^{\circ} 20^{\prime}$ & 27 & $\mathrm{x}$ & $\mathrm{x}$ & \\
\hline 40 & $55^{\circ} 11^{\prime}$ & $02^{\circ} 20^{\prime}$ & 32 & & $\mathrm{x}$ & \\
\hline 42 & $55^{\circ} 27^{\prime}$ & $02^{\circ} 20^{\prime}$ & 44 & $\mathrm{x}$ & $\mathrm{x}$ & $\mathrm{x}$ \\
\hline 43 & $55^{\circ} 11^{\prime}$ & $01^{\circ} 40^{\prime}$ & 36 & $\mathrm{x}$ & $\mathrm{x}$ & $\mathrm{x}$ \\
\hline 45 & $54^{\circ} 47^{\prime}$ & $01^{\circ} 40^{\prime}$ & 23 & $\mathrm{x}$ & $\mathrm{x}$ & $\mathrm{x}$ \\
\hline 47 & $54^{\circ} 31^{\prime}$ & $01^{\circ} 40^{\prime}$ & 18 & $\mathrm{x}$ & $\mathrm{x}$ & $\mathrm{x}$ \\
\hline 49 & $54^{\circ} 23^{\prime}$ & $01^{\circ} 40^{\prime}$ & 48 & $\mathrm{x}$ & $\mathrm{x}$ & $\mathrm{x}$ \\
\hline 51 & $54^{\circ} 07^{\prime}$ & $01^{\circ} 40^{\prime}$ & 68 & $\mathrm{x}$ & & $\mathrm{x}$ \\
\hline 54 & $54^{\circ} 10^{\prime}$ & $01^{\circ} 00^{\prime}$ & 45 & $\mathrm{x}$ & $\mathrm{x}$ & $\mathrm{x}$ \\
\hline 56 & $54^{\circ} 31^{\prime}$ & $01^{\circ} 00^{\prime}$ & 55 & & $\mathrm{x}$ & $\mathrm{x}$ \\
\hline 58 & $54^{\circ} 47^{\prime}$ & $01^{\circ} 00^{\prime}$ & 50 & $\mathrm{x}$ & $\mathrm{x}$ & $\mathrm{x}$ \\
\hline 60 & $55^{\circ} 03^{\prime}$ & $01^{\circ} 00^{\prime}$ & 61 & & $\mathrm{x}$ & $\mathrm{x}$ \\
\hline
\end{tabular}


and Ryland 1990 and references therein; Künitzer et al. 1992; Hartmann-Schröder 1996; Dauwe et al. 1998).

Generally, interface-feeders are capable of alternative suspension and surface-deposit feeding dependent on flow conditions. Symbiotic deposit feeders are those species which utilize symbiotic (e.g. sulphate-reducing) bacteria in their nutrition (e.g. lucinid clams). In addition to the classical classification, we distinguished two additional feeding types: species that clean their food off sand grains were separated from subsurface deposit feeders and classified as sandlickers (Remane 1940). Since Anthozoa and Corymorpha nutans are known to feed mainly on pelagic copepods and harpacticoids swimming in the water column at night (Eleftheriou and Basford 1983; Holohan et al. 1998), these species were separated from suspension feeders and predators as hyperbenthos predators.

\section{Sediments}

Fine fraction $(<63 \mu \mathrm{m})$ content. The fine fraction $(<63 \mu \mathrm{m})$ content at each station was analysed using the "Analysette 22 Economy" laser particle sizer (Fritsch, Germany). Frozen sediment was freeze-dried. Samples were sieved with a $1,000 \mu \mathrm{m}$ sieve to remove shell particles and macroalgae. An aliquot of each sample was placed in the laser particle sizer and automatically homogenized with a stirrer and by ultrasonication. Although this method provides the percentage of different grain size fractions, we only used the grain size fraction $<63 \mu \mathrm{m}$ (mud) for further statistical analysis.

Organic carbon and nitrogen contents and $\mathrm{C} / \mathrm{N}$ ratio. According to Wirth and Wiesner (1988), higher total organic carbon (TOC) of the total sediment $\left(\mathrm{TOC}_{\text {tot }}\right)$ is primarily related to the higher ratio of clay/silt to sand and, thus, to the hydrodynamic regime. In contrast, the increase in TOC content of the fine fraction $\left(\mathrm{TOC}_{<63 \mu \mathrm{m}}\right)$ arises from a local admixing of varying amounts of small sized organic-rich particles to an otherwise low and constant TOC background, probably as a response to direct planktonic inputs or temporary deposition of suspended matter. Therefore, TOC, total nitrogen $(\mathrm{TN})$ and $\mathrm{C} / \mathrm{N}$ ratio were analysed for the total sediment $\left(\mathrm{TOC}_{\text {tot }}, \mathrm{TN}_{\text {tot }}\right.$ and $\mathrm{C} / \mathrm{N}_{\text {tot }}$ ) as well as for the fine fraction $<63 \mu \mathrm{m}$ $\left(\mathrm{TOC}_{<63 \mu \mathrm{m}}, \mathrm{TN}_{<63 \mu \mathrm{m}}\right.$ and $\mathrm{C} / \mathrm{N}_{<63 \mu \mathrm{m}}$ ). The fraction $<63 \mu \mathrm{m}$ was separated by wet sieving over $63 \mu \mathrm{m}$ mesh size to determine variables related to the fine fraction. Analyses of total sediment organic carbon and nitrogen were performed on freeze-dried samples that were powdered and homogenized.

For all sediment fractions an aliquot of $10-30 \mathrm{mg}$ was combusted at $1,010^{\circ} \mathrm{C}$ in a Heraeus $\mathrm{C} / \mathrm{N}$ analyser following acidification of the samples with concentrated $\mathrm{HCl}$ in a desiccator to remove inorganic carbonates.

\section{Statistics}

The PRIMER 5 (Plymouth routines in multivariate ecological research) software package was used for statistical analyses of faunal data. MDS analyses (Kruskal and Wish 1978) were performed. The data were transformed using double square roots. Similarities were calculated using the Bray-Curtis coefficient. Characteristic species which contribute most to the similarity of the station groups were identified using the SimPer (similarity percentage) tool.

The environmental data were analysed for subsets of abiotic variables whose multidimensional patterns corresponded best with those of the species data using the Bio-Env tool.

Canonical correspondence analysis (CCA) was performed with Canoco software (Microcomputer Power, Ithaca, N.Y.). CCA was applied to evaluate correlations between environmental variables, species and variance in site patterns. The Monte Carlo permutation test was used to check the statistical validity of these associations.

The Kolmogorov-Smirnov test was applied to test which data were normally distributed. In the case of normal distribution we applied Pearson's product moment correlation to calculate the correlation between two variables. Otherwise, Spearman rank correlation was applied.

The spatial patterns were interpolated using the inverse distance weighted interpolator.
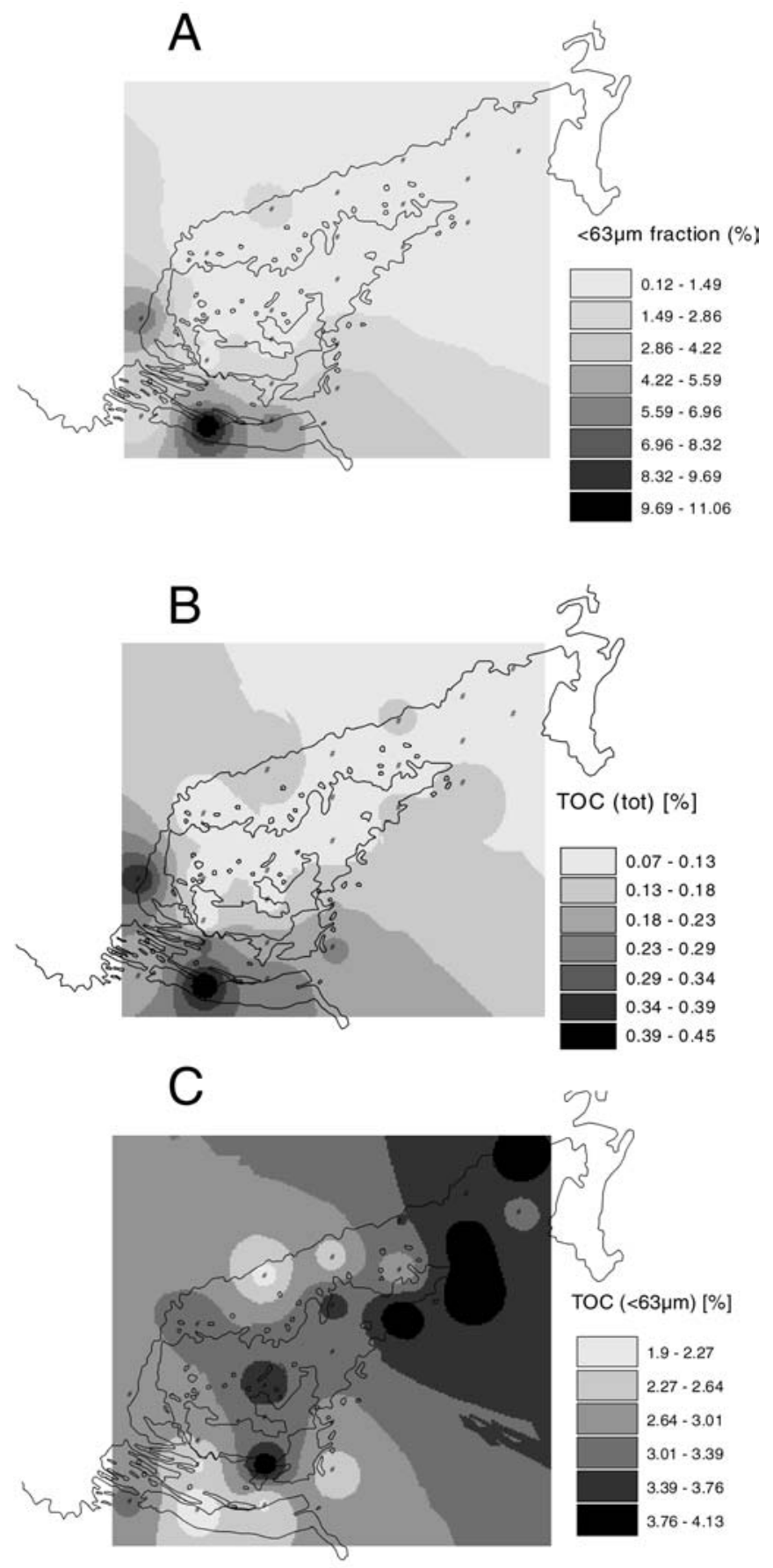

Fig. 2 Spatial distribution of $\mathbf{A}$ the sediment fine fraction $(<63 \mu \mathrm{m})$ content $(\%)$, B total organic carbon (TOC) content of the total sediment $\left(T O C_{t o t}\right)(\%)$ and $\mathbf{C}$ TOC of the fine fraction $(<63 \mu \mathrm{m})\left(\right.$ TOC $\left._{<63 \mu \mathrm{m}}\right)(\%)$ in May 1996

\section{Results}

\section{Sediment}

\section{Fine fraction content}

The content of the fine fraction $(<63 \mu \mathrm{m})$ was significantly correlated to water depth (Table 2, Fig. 2A). The 
Table $2 \mathrm{C} / \mathrm{N}$ ratios, total organic carbon (TOC) and nitrogen contents in total surface sediments (tot) as well as in the fine fraction $(<63 \mu \mathrm{m})$ contents in May 1996. C/N ratios are raw data, TOC and TN contents (\%) are rounded, - no sample

\begin{tabular}{|c|c|c|c|c|c|c|c|}
\hline Station & Fraction $<63 \mu \mathrm{m}(\%)$ & $\mathrm{TOC}_{\mathrm{tot}}(\%)$ & $\mathrm{N}_{\text {tot }}(\%)$ & $\mathrm{C} / \mathrm{N}_{\text {tot }}$ & $\mathrm{TOC}_{<63 \mu \mathrm{m}}(\%)$ & $\mathrm{N}_{<63 \mu \mathrm{m}}(\%)$ & $\mathrm{C} / \mathrm{N}_{<63 \mu \mathrm{m}}$ \\
\hline 6 & 0.12 & 0.079 & 0.02 & 5.8 & 3.25 & 0.45 & 8.8 \\
\hline 8 & 0.41 & 0.101 & 0.02 & 5.5 & 3.98 & 0.44 & 7.4 \\
\hline 9 & 0.67 & 0.122 & 0.02 & 6.2 & 3.65 & 0.43 & 8.4 \\
\hline 11 & 0.26 & 0.107 & 0.02 & 6 & 4.01 & 0.45 & 9.1 \\
\hline 13 & 1.46 & 0.172 & 0.03 & 6.9 & 4.03 & 0.48 & 8.5 \\
\hline 16 & 0.98 & 0.148 & 0.03 & 5.2 & 4.13 & 0.56 & 7.4 \\
\hline 18 & 0.24 & 0.087 & 0.02 & 5.4 & 2.71 & 0.3 & 9 \\
\hline 20 & 1 & 0.147 & 0.03 & 5 & 3.40 & 0.38 & 8.9 \\
\hline 21 & 1.07 & 0.128 & 0.02 & 6.6 & 2.45 & 0.26 & 9.4 \\
\hline 23 & 0.33 & 0.109 & 0.02 & 6 & 3.53 & 0.43 & 8.3 \\
\hline 25 & 0.58 & 0.111 & 0.02 & 5.8 & 3.02 & 0.35 & 8.6 \\
\hline 27 & 2.37 & 0.186 & 0.03 & 7.1 & 2.85 & 0.3 & 9.4 \\
\hline 29 & 3.79 & 0.247 & 0.04 & 6.9 & 2.37 & 0.26 & 9.4 \\
\hline 32 & 6.07 & 0.291 & 0.04 & 7.2 & 2.23 & 0.29 & 7.6 \\
\hline 34 & 1.76 & 0.19 & 0.03 & 6.5 & 4.07 & 0.58 & 7 \\
\hline 36 & 0.43 & 0.115 & 0.02 & 6.1 & 3.31 & 0.36 & 9.2 \\
\hline 38 & 0.34 & 0.128 & 0.02 & 5.9 & 3.76 & 0.48 & 7.8 \\
\hline 42 & 1.97 & 0.176 & 0.03 & 6.8 & 2.16 & 0.23 & 9.3 \\
\hline 43 & 0.48 & 0.098 & 0.02 & 5.6 & 3.15 & 0.37 & 8.5 \\
\hline 45 & 0.39 & 0.082 & 0.02 & 5.2 & - & - & - \\
\hline 47 & 0.63 & 0.071 & 0.01 & 6.3 & 2.65 & 0.38 & 7 \\
\hline 49 & 4.62 & 0.317 & 0.03 & 9.7 & 2.23 & 0.28 & 7.9 \\
\hline 51 & 11.07 & 0.448 & 0.05 & 8.4 & 1.90 & 0.19 & 10 \\
\hline 54 & 1.71 & 0.191 & 0.03 & 6.7 & 3.10 & 0.34 & 9.1 \\
\hline 58 & 6.55 & 0.39 & 0.05 & 7.8 & 2.76 & 0.28 & 10 \\
\hline
\end{tabular}

shallow and the eastern parts of the Dogger Bank showed the lowest values (station 38: $0.34 \%$, station 45 : $0.38 \%$ ), and the mud content increased towards the deeper south-western sites. Fine fraction contents of the deeper southern stations were higher (station 32: $6.07 \%$, station 51: $11.07 \%$ in the Outer Silver Pit) than those of the deeper northern stations (station 42: 1.97\%).

\section{TOC, TN and C/N of the total sediment}

$\mathrm{TOC}_{\text {tot }}, \mathrm{TN}_{\text {tot }}$ and $\mathrm{C} / \mathrm{N}_{\text {tot }}$ showed nearly the same spatial pattern as the fine fraction content, as they correlated positively with the fine fraction content (Table 2). Values were lowest in the shallow and in the eastern parts of the Dogger Bank, and increased towards the deeper southwestern part (Fig. 2B). $\mathrm{TN}_{\text {tot }}$ values were very low and varied little, ranging between $0.02 \%$ and $0.04 \%$ (Table 2).

\section{TOC, TN and C/N of the fine fraction}

The values measured for the fine fraction showed a much more variable spatial pattern. In general, highest $\mathrm{TOC}_{<63 \mu \mathrm{m}}$ and $\mathrm{TN}_{<63 \mu \mathrm{m}}$ contents were found in the eastern part of the Dogger Bank (Fig. 2C, Table 2), but the values decreased towards the deeper southern parts characterized by muddy fine sands, and towards the deeper central northern stations (42 and 21). Locally higher $\mathrm{TOC}_{<63 \mu \mathrm{m}}$ contents were measured on top of the Dogger Bank (stations 34 and 38) and on station 54 in the western part.

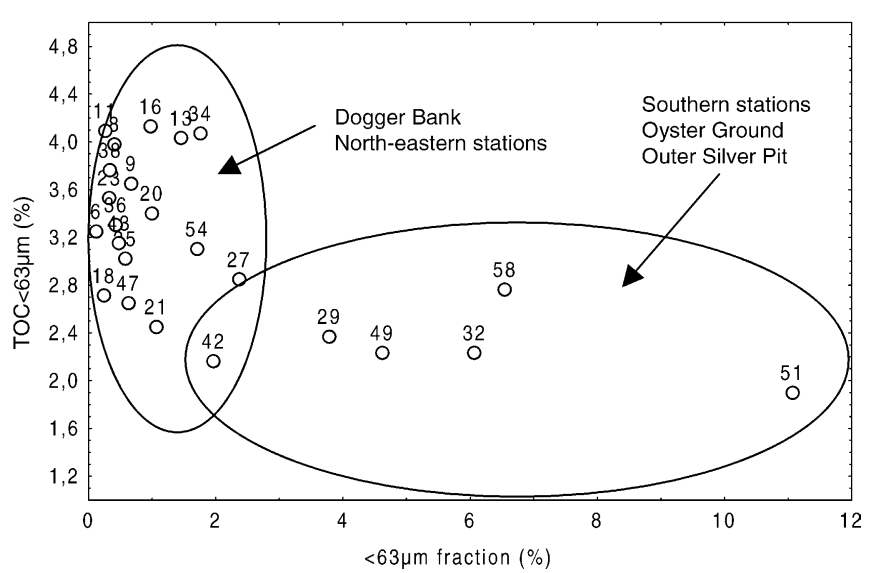

Fig. 3 Scatterplot showing TOC $_{<63 u m}$ in relation to the fine fraction $(<63 \mu \mathrm{m})$ content of sediments in May 1996

$\mathrm{C} / \mathrm{N}_{<63 \mu m}$ ratio increased with depth ranging between 7 in the shallow and 10 in the deeper parts (Table 2). However, there were some deviations from this pattern, such as station 36 on top of the Bank (C/N 9.2), and station 32 in the Outer Silver Pit (C/N 7.6).

Overall, two types of sediment could be distinguished for the Dogger Bank (Fig. 3). Sediments of the Outer Silver Pit and the Oyster Ground (the southern stations) covered quite a narrow range of $\mathrm{TOC}_{<63 \mathrm{um}}(1.9-2.5 \%)$ of the entire fine fraction content between $2 \%$ and $13 \%$. The sediments of the Dogger Bank and towards the central North Sea displayed higher $\mathrm{TOC}_{<63 \mu \mathrm{m}}$ values (2.16-4.12\%) at comparable fine fraction contents. 
Table 3 Macrofaunal species number per $0.4 \mathrm{~m}^{2}$ and macrofaunal abundance per $\mathrm{m}^{2}$ in May 1996-1998. SD standard deviation, Com Communities: B Bank, NE North-eastern, SA SouthernAmphiura,
SW South-West Patch, WA Western Amphiura, WT Western transitional, - no sample

\begin{tabular}{|c|c|c|c|c|c|c|c|c|c|c|c|}
\hline \multirow{2}{*}{$\begin{array}{l}\text { Station } \\
\text { no }\end{array}$} & \multirow[t]{2}{*}{ Com } & \multicolumn{5}{|c|}{ Species number } & \multicolumn{5}{|c|}{ Abundance } \\
\hline & & 1996 & 1997 & 1998 & Mean & $\mathrm{SD}$ & 1996 & 1997 & 1998 & Mean & SD \\
\hline 6 & B & 45 & - & 41 & 43 & 3 & 763 & - & 5,130 & 2,947 & 3,088 \\
\hline 8 & $\mathrm{NE}$ & 28 & 56 & 57 & 47 & 16 & 435 & 1,335 & 1,583 & 1,118 & 604 \\
\hline 9 & $\mathrm{NE}$ & 51 & 56 & 44 & 50 & 6 & 1,103 & 1,168 & 573 & 948 & 326 \\
\hline 11 & B & 46 & 64 & 44 & 51 & 11 & 1,155 & 1,405 & 1,188 & 1,249 & 136 \\
\hline 13 & SA & 42 & 50 & 52 & 48 & 5 & 1,595 & 1,448 & 2,608 & 1,884 & 632 \\
\hline 16 & $\mathrm{~B}$ & 39 & 40 & 33 & 37 & 4 & 1,438 & 1,098 & 2,305 & 1,614 & 622 \\
\hline 18 & B & 48 & 49 & 49 & 49 & 1 & 948 & 1,090 & 1,348 & 1,129 & 203 \\
\hline 20 & $\mathrm{NE}$ & 47 & 59 & 57 & 54 & 6 & 575 & 630 & 420 & 542 & 109 \\
\hline 21 & $\mathrm{NE}$ & 58 & 53 & 48 & 53 & 5 & 723 & 903 & 798 & 808 & 90 \\
\hline 23 & B & 54 & 55 & 48 & 52 & 4 & 1,035 & 1,428 & 1,198 & 1,220 & 197 \\
\hline 25 & B & 51 & 60 & 45 & 52 & 8 & 1,040 & 1,553 & 1,253 & 1,282 & 258 \\
\hline 27 & B & 48 & 46 & 43 & 46 & 3 & 1,080 & 1,043 & 1,128 & 1,084 & 43 \\
\hline 29 & SA & 42 & 42 & 57 & 47 & 9 & 675 & 1,515 & 2,328 & 1,506 & 827 \\
\hline 32 & SA & 32 & 38 & 42 & 37 & 5 & 953 & 1,415 & 1,325 & 1,231 & 245 \\
\hline 34 & B & 48 & 49 & 47 & 48 & 1 & 1,035 & 2,258 & 1,525 & 1,606 & 616 \\
\hline 36 & B & 46 & 43 & 54 & 48 & 6 & 1,053 & 2,003 & 1,210 & 1,422 & 509 \\
\hline 38 & B & 42 & 44 & - & 43 & 1 & 1,238 & 1,215 & - & 1,227 & 16 \\
\hline 40 & B & - & 65 & - & 65 & - & - & 1,543 & - & 1,543 & - \\
\hline 42 & $\mathrm{NE}$ & 46 & 59 & 60 & 55 & 8 & 580 & 1,160 & 665 & 802 & 313 \\
\hline 43 & $\mathrm{NE}$ & 47 & 41 & 37 & 42 & 5 & 788 & 930 & 275 & 664 & 345 \\
\hline 45 & SW & 35 & 20 & 28 & 28 & 8 & 623 & 935 & 833 & 797 & 159 \\
\hline 47 & SW & 10 & 19 & 22 & 17 & 6 & 223 & - & 475 & 349 & 178 \\
\hline 49 & $\mathrm{SA}$ & 54 & 65 & 53 & 57 & 7 & 1,363 & 4,158 & 1,588 & 2,370 & 1,553 \\
\hline 51 & WA & 45 & - & 54 & 50 & 6 & 693 & - & 1,063 & 878 & 262 \\
\hline 54 & WT & 44 & 64 & 59 & 56 & 10 & 840 & 1,255 & 1,518 & 1,204 & 342 \\
\hline 56 & WT & - & 53 & 47 & 50 & 4 & - & 1,080 & 510 & 795 & 403 \\
\hline 58 & WA & 45 & 46 & 36 & 42 & 6 & 1,023 & 1,438 & 753 & 1,071 & 345 \\
\hline 60 & WA & - & 65 & 51 & 58 & 10 & - & 1,408 & 643 & 1,026 & 541 \\
\hline
\end{tabular}

\section{Macrofauna}

Note that in the figures some data are given exemplarily for May 1996 only, whereas the other data are given as means for the whole study period 1996-1998. MDS ordination plots for the different communities in May 1996-1998 are presented in Wieking and Kröncke (2001).

\section{Species number and macrofauna abundance}

A total of 269 taxa was identified for the three cruises in May 1996-1998.

Mean species number per year and station was 47 species $/ 0.4 \mathrm{~m}^{2}$ (Table 3 ). The maximum value $(65$ species $/ 0.4 \mathrm{~m}^{2}$ ) was reached at stations 40,49 and 60 in May 1997. Generally, higher species numbers (more than 50 species $/ 0.4 \mathrm{~m}^{2}$ ) were found along the northern slope of the Dogger Bank (>30 m depth) and in the deeper south-western part. Species number was lower at the shallow stations on top of the Bank, and dropped to 17 species $/ 0.4 \mathrm{~m}^{2}$ at the shallowest station 47 on the South-West Patch. No correlation was found between species number and measured environmental variables.

Mean abundance per year and station was 1,225 $\mathrm{ind} / \mathrm{m}^{2}$ (Table 3). Maximum abundance was found at sta- tion $6\left(2,947 \mathrm{ind} / \mathrm{m}^{2}\right)$. Mean abundance was lower at the northern slope of the Dogger Bank, but minimum abundance was found again at station $47\left(349 \mathrm{ind} / \mathrm{m}^{2}\right)$. For the rest of the investigated area, mean abundance ranged between $878 \mathrm{ind} / \mathrm{m}^{2}$ and $2,370 \mathrm{ind} / \mathrm{m}^{2}$ without obvious spatial trends. Generally, the lowest abundances were recorded in May 1996, which has already been discussed by Wieking and Kröncke (2001) in relation to the extraordinary cold winter of 1995/1996. Total abundance was correlated positively to $\mathrm{TOC}_{<63 \mu \mathrm{m}}$.

\section{Macrofauna communities}

In the area of investigation we separated five groups of stations by means of non-metric MDS and CCA (Figs. 4, 5). In general, the macrobenthic fauna on top of the Dogger Bank (Bank community, South-West Patch community) was different from the fauna of the surrounding deeper areas (Southern and Western Amphiura communities, North-eastern community) (Fig. 5, Table 4). According to the Bio-Env procedure, a combination of depth, $\mathrm{TOC}_{\text {tot }}, \mathrm{TN}_{\text {tot }}(\rho=0.636)$ and depth, fine fraction $(<63 \mu \mathrm{m}), \mathrm{TN}_{\text {tot }}(\rho=0.633)$ best matches the ordination of the macrofaunal abundance data, which is also reflected in the CCA triplot. The addition of further factors does not increase the fit of the multivariate data. In the fol- 
Table 4 Abundance and feeding types of characteristic species (ind $/ \mathrm{m}^{2}$ ) for the different communities found on the Dogger Bank in May 1996-1998. Species are ordered in decreasing contribution to similarity, as indicated by SimPer for the $\sqrt{ } \sqrt{ }$ transformed abun- dance data; $H P$ hyperbenthos predator, $I F$ interface feeder, $P$ predator, $S D$ surface deposit feeder, $S L$ sandlicker, $S S D$ subsurface deposit feeder, $S y D$ symbiotic deposit feeder, $U$ unknown

\begin{tabular}{|c|c|c|c|c|c|c|c|c|}
\hline \multicolumn{3}{|l|}{ Bank community } & \multicolumn{3}{|c|}{ South-West Patch community } & \multicolumn{3}{|l|}{ North-eastern community } \\
\hline Magelona johnstonii & IF & 74 & Nephtys cirrosa & $\mathrm{P}$ & 60 & Bathyporeia elegans & SL & 114 \\
\hline Bathyporeia elegans & SL & 158 & Donax vittatus & $\mathrm{SF}$ & 44 & Polinices pulchellus & $\mathrm{P}$ & 15 \\
\hline Fabulina fabula & $\mathrm{IF}$ & 85 & Polinices pulchellus & $\mathrm{P}$ & 21 & Perioculodes longimanus & $\mathrm{U}$ & 17 \\
\hline Bathyporeia guilli. & SL & 83 & Pontocrates arenarius & $\mathrm{U}$ & 15 & Chaetozone sp. F group & SD & 12 \\
\hline Polinices pulchellus & $\mathrm{P}$ & 39 & Perioculodes longimanus & $\mathrm{U}$ & 9 & Edwardsiidae spp. & HP & 24 \\
\hline Phoronis mülleri & $\mathrm{SF}$ & 11 & Magelona johnstonii & IF & 4 & Cerianthus lloydii & HP & 62 \\
\hline Owenia fusiformis & IF & 13 & & & & Gari fervensis & SF & 11 \\
\hline Nephtys assimilis & $\mathrm{P}$ & 7 & & & & Ophelia borealis & SSD & 10 \\
\hline Bathyporeia tenuipes & SL & 27 & & & & Abra prismatica & SD & 26 \\
\hline Spio cf. decorata & IF & 24 & & & & Magelona johnstonii & IF & 14 \\
\hline Chaetozone sp. F group & $\mathrm{SD}$ & 11 & & & & Amphiura filiformis & IF & 14 \\
\hline $\begin{array}{l}\text { Mean total abundance } \\
\text { per } \mathrm{m}^{2}\end{array}$ & & 1,184 & & & 573 & & & 813 \\
\hline $\begin{array}{l}\text { Mean species number } \\
\text { per } 0.4 \mathrm{~m}^{2}\end{array}$ & & 49 & & & 23 & & & 50 \\
\hline
\end{tabular}

Southern Amphiura community

Western Amphiura community

Amphiura

Amphiura filiformis

Mysella bidentata

Spiophanes bombyx

Pholoe baltica

Magelona filiformis

Polinices pulchellus

Nemertini spp.

Nucula nitidosa

Echinocardium cordatum

Phaxas pellucidus

Bathyporeia tenuipes

Harpinia antennaria

Tellimya ferruginosa

Cylichna cylindracea

Thyasira flexuosa

Nephtys hombergii

Diplocirrus glaucus

Phoronis mülleri

Scoloplos armiger

Abra alba

Mean total abundance

per $\mathrm{m}^{2}$

Mean species number

per $0.4 \mathrm{~m}^{2}$

Amphiura filiformis
Pholoe baltica
Spiophanes bombyx
Diplocirrus glaucus
Mysella bidentata
Phoronis mülleri
Nemertini spp.
Cylichna cylindracea
Phaxas pellucidus
Lucinoma borealis
Nucula nitidosa
Harpinia antennaria
Scoloplos armiger
Edwardsiidae spp.
Echinocardium cordatum
Thyasira flexuosa
Nephtys hombergii
Nuculoma tenuis
Eudorellopsis deformis
Goniada maculata

47
Transitional

$\begin{array}{lrl}\text { IF } & 376 & \text { Amphiura filiformis } \\ \mathrm{P} & 33 & \text { Spiophanes bombyx } \\ \mathrm{IF} & 109 & \text { Scoloplos armiger } \\ \mathrm{SD} & 23 & \text { Bathyporeia elegans } \\ \mathrm{SF} & 36 & \text { Goniada maculata } \\ \mathrm{SF} & 16 & \text { Echinocyamus pusillus } \\ \mathrm{P} & 14 & \text { Polinices pulchellus } \\ \mathrm{P} & 16 & \text { Ophelia borealis } \\ \mathrm{SF} & 10 & \text { Phaxas pellucidus } \\ \mathrm{SyD} & 8 & \text { Phoronis mülleri } \\ \mathrm{SD} & 22 & \text { Cochlodesma pratenue } \\ \mathrm{U} & 13 & \text { Owenia fusiformis } \\ \mathrm{SSD} & 13 & \text { Sthenelais limicola } \\ \mathrm{HP} & 7 & \text { Edwardsiidae spp. } \\ \mathrm{SD} & 4 & \text { Nephtys assimilis } \\ \mathrm{SyD} & 5 & \text { Echinocardium cordatum } \\ \mathrm{P} & 8 & \text { Bathyporeia guilliamsoniana } \\ \mathrm{SSD} & 21 & \text { Amphiura brachiata } \\ \mathrm{SL} & 13 & \text { Abra prismatica } \\ \mathrm{P} & 5 & \text { Nemertini spp. } \\ & 992 & \end{array}$

$\begin{array}{lr}\text { IF } & 103 \\ \text { IF } & 182 \\ \text { SSD } & 44 \\ \text { SL } & 85 \\ \text { P } & 11 \\ \text { SL } & 199 \\ \text { P } & 13 \\ \text { SSD } & 58 \\ \text { SF } & 14 \\ \text { SF } & 8 \\ \text { SF } & 6 \\ \text { IF } & 7 \\ \text { P } & 7 \\ \text { HP } & 10 \\ \text { P } & 4 \\ \text { SD } & 3 \\ \text { SL } & 4 \\ \text { IF } & 15 \\ \text { SD } & 12 \\ \text { P } & 6 \\ & 1,000\end{array}$

50 lowing sections, the five communities are characterized in detail.

Bank community. Especially at the shallow stations $(<25 \mathrm{~m})$ the Bank community was dominated by the amphipods Bathyporeia elegans $\left(158 \mathrm{ind} / \mathrm{m}^{2}\right)$ and $B$. guilliamsoniana $\left(83 \mathrm{ind} / \mathrm{m}^{2}\right)$. At deeper stations $(>25 \mathrm{~m})$ the abundances of the tellinid bivalve Fabulina fabula (85 ind $/ \mathrm{m}^{2}$ ), the ophiurid Amphiura brachiata (83 ind $/ \mathrm{m}^{2}$ ) and the polychaetes Spiophanes bombyx (514 ind $\left./ \mathrm{m}^{2}\right)$, Magelona johnstoni $\left(74 \mathrm{ind} / \mathrm{m}^{2}\right)$, M. filiformis (30 ind $\left./ \mathrm{m}^{2}\right)$, Spio cf. decorata $\left(24 \mathrm{ind} / \mathrm{m}^{2}\right)$ and Owenia fusiformis $\left(13 \mathrm{ind} / \mathrm{m}^{2}\right)$ were higher (Table 4). With regard to feeding types, this community was domi- 


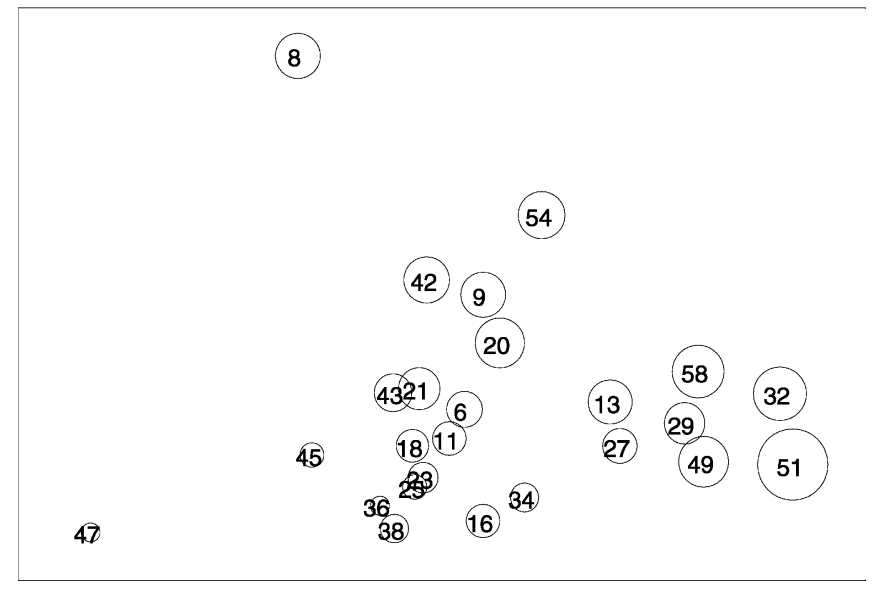

Fig. 4 MDS ordination of the $\sqrt{ } \sqrt{ }$ transformed abundance data from May 1996 only. Relative depth is superimposed by the size of the circles (Stress 0.11). Numbers are station numbers

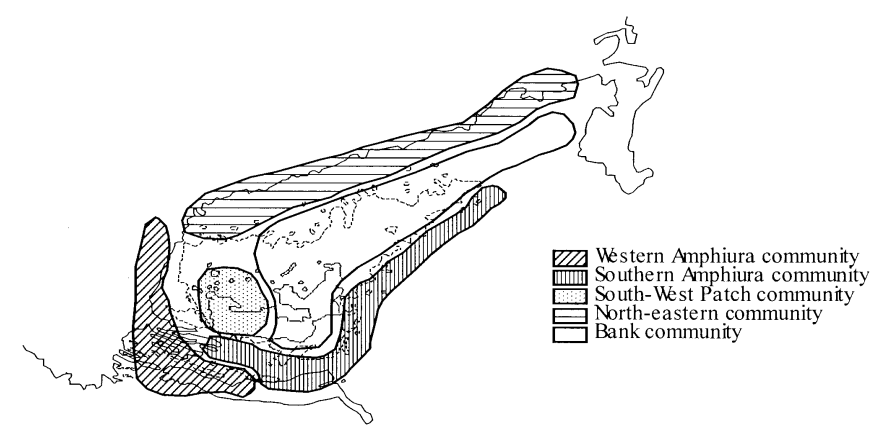

Fig. 5 Spatial distribution of macrofauna communities in the study area in May 1996-1998

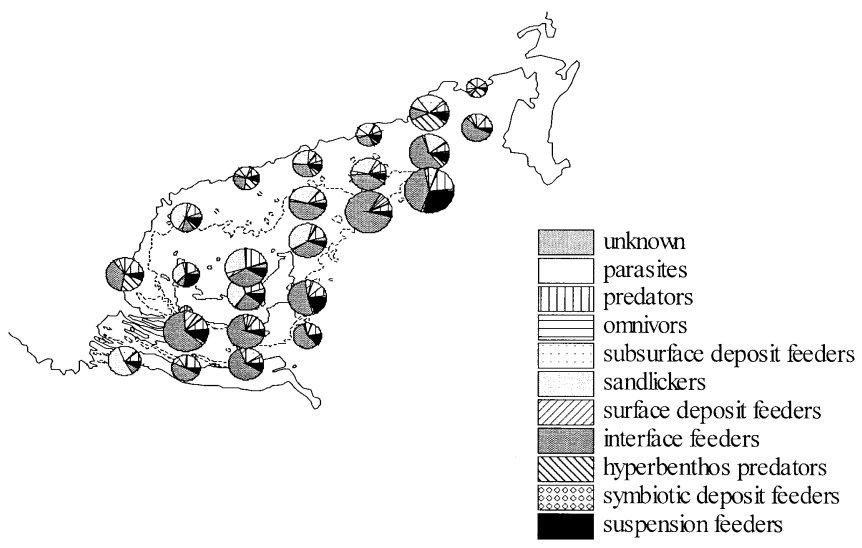

Fig. 6 Trophic structure of macrofauna represented by the abundance of feeding types in May 1996

nated by interface-feeding species, such as the polychaetes and A. brachiata, contributing up to $60 \%$ to the total abundance (Fig. 6). The second most important group comprised sandlicking amphipods and cumaceans. The most important predator of the Bank community was the naticid gastropod, Polinices pulchellus (39 ind $/ \mathrm{m}^{2}$ ).
South-West Patch community. Stations at the South-West Patch (stations 45 and 47) formed a subgroup of the Bank community. The South-West Patch fauna was characterized by an impoverished Bank fauna with low species and individual numbers (Tables 3, 4). Dominant species were Bathyporeia elegans $\left(192 \mathrm{ind} / \mathrm{m}^{2}\right.$ ) and B. guilliamsoniana, with lower abundances than at the other stations on top of the bank ( $\left.75 \mathrm{ind} / \mathrm{m}^{2}\right)$, but Donax vittatus $\left(44 \mathrm{ind} / \mathrm{m}^{2}\right)$ and Nephtys cirrosa $\left(60 \mathrm{ind} / \mathrm{m}^{2}\right)$ showed their highest abundances at these stations (Table 4). Concerning the trophic structure, in particular the numbers and abundances of interface-feeding polychaetes were lower in the South-West Patch community compared to the Bank community (Fig. 6). In contrast, sandlickers dominated the community throughout the three years. The comparatively high contribution of predators was due to the occurrence of the small predatory polychaete, N. cirrosa.

North-eastern community. Along the northern slope and towards the north-eastern part of the Dogger Bank, stations were inhabited by a transitional community and the fauna also changed with depth (Figs. 4, 5). The fauna of shallower stations close to the bank (mainly stations 21 and 43) was still rather similar to the Bank fauna [Spiophanes bombyx (125 ind $\left./ \mathrm{m}^{2}\right)$, Bathyporeia elegans (114 ind $\left./ \mathrm{m}^{2}\right)$ and Polinices pulchellus $\left.\left(15 \mathrm{ind} / \mathrm{m}^{2}\right)\right]$, but in addition Cerianthus lloydii (62 ind $/ \mathrm{m}^{2}$ ) and Echinocyamus pusillus $\left(20 \mathrm{ind} / \mathrm{m}^{2}\right)$ occurred at high abundances (Table 4). The deepest northern stations (mainly stations $8,9,20,42$ ) were characterized by higher abundances of Amphiura filiformis (14 ind $\left./ \mathrm{m}^{2}\right)$, Abra prismatica $(26$ ind $/ \mathrm{m}^{2}$ ) and Scoloplos armiger (59 ind $/ \mathrm{m}^{2}$ ). Generally, hardly any dominance of species was found in the northeastern part, but many species contributed similarly to the total abundance. Among these were several rare species known from the northern North Sea such as Aricidea cerrutii and $A$. simonae, as well as species preferring coarser sediments, such as Ophiura affinis and Pisione remota.

The latter findings were also reflected in a comparatively high structural and functional diversity (Fig. 6). Nonetheless, some feeding types, such as hyperbenthos predators (Cerianthus lloydii, C. nutans) and sandlickers (Echinocyamus pusillus), showed locally high abundances.

Southern Amphiura filiformis community. Towards the southern stations in water depths $>35 \mathrm{~m}$, the Bank community changed and was finally dominated by Amphiura filiformis $\left(640 \mathrm{ind} / \mathrm{m}^{2}\right)$. These changes were correlated to an increase in the fine fraction $(<63 \mu \mathrm{m})$ content. Pholoe baltica $\left(66 \mathrm{ind} / \mathrm{m}^{2}\right)$, Mysella bidentata $\left(127 \mathrm{ind} / \mathrm{m}^{2}\right)$ and Nucula nitidosa $\left(61 \mathrm{ind} / \mathrm{m}^{2}\right)$ were also important parts of the fauna present in this area (Table 4).

Despite the significant change in faunal composition, this community was also dominated by interface-feeding species [Amphiura filiformis and, locally, Spiophanes bombyx $\left(300 \mathrm{ind} / \mathrm{m}^{2}\right)$ ]. Subsurface deposit feeders (e.g. 
Fig. 7A-D MDS ordination of the $\sqrt{ } \sqrt{ }$ transformed abundance data from May 1996. Relative abundance of $\mathbf{A}$ interface feeders, B surface deposit feeders, $\mathbf{C}$ sandlickers and $\mathbf{D}$ subsurface deposit feeders is superimposed by the size of the circles
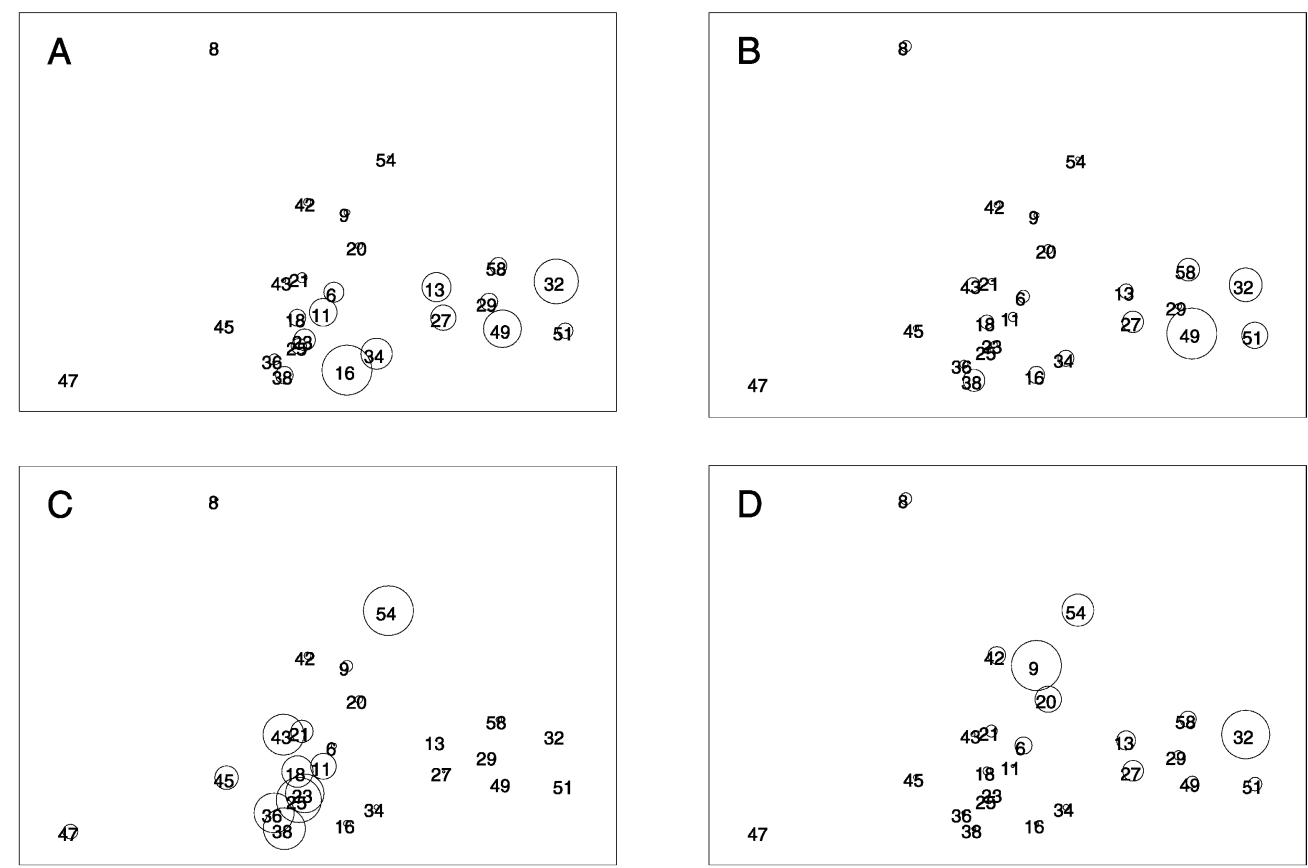

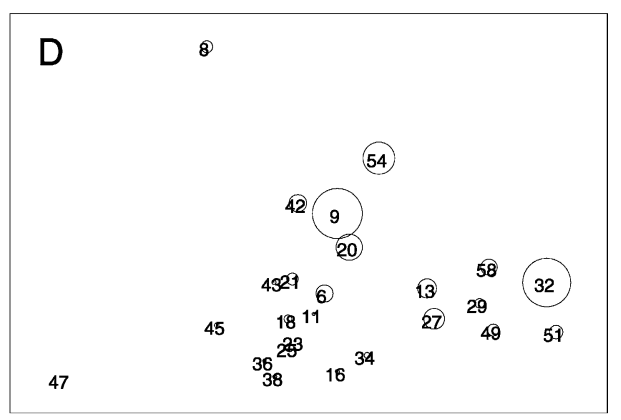

Amphictene auricoma, Lagis koreni, Nucula nitidosa), the second most important feeding type, as well as surface deposit feeders (Diplocirrus glaucus, Abra alba) appeared in highest abundances in this community (Fig. 7B, D). Suspension feeders were mainly represented by the bivalve Mysella bidentata, a commensal of Amphiura filiformis.

Western Amphiura filiformis community. Although similar in abundance of the dominant species Amphiura filiformis (376 ind $\left./ \mathrm{m}^{2}\right)$, Pholoe baltica (33 ind $\left./ \mathrm{m}^{2}\right)$, Spiophanes bombyx $\left(109 \mathrm{ind} / \mathrm{m}^{2}\right)$ and Mysella bidentata (36 ind $/ \mathrm{m}^{2}$ ), the remaining associated fauna of the Amphiura community changed in the Outer Silver Pit and towards the deeper western parts (Table 4). In this area the number of species typical for the northern North Sea [e.g. Nuculoma tenuis $\left(21 \mathrm{ind} / \mathrm{m}^{2}\right)$, Lucinoma borealis $\left(8 \mathrm{ind} / \mathrm{m}^{2}\right)$, Amparete falcata $\left.\left(33 \mathrm{ind} / \mathrm{m}^{2}\right)\right]$ was higher than in the southern part of the Amphiura community. Especially at station 51, up to ten individuals of different large and long-lived species were found in both grabs (e.g. Acanthocardia echinata, Priapulus caudatum, Brissopsis lyrifera, Pectinaria belgica, Leptosynapta inhaerens and Glycera spp.).

Due to the occurrence of spatial and temporal variable sand banks and ripples (the Hills) the morphological heterogeneity was high in this area (Fig. 1). Therefore, spatial variability can hardly be separated from temporal variability throughout the period of investigation. Generally, the fauna of the deep stations with lower mud contents (Western transitional, mainly stations 54 and 56) differed from those with higher mud contents (Western Amphiura community, mainly stations 51, 58, 60). Western transitional stations showed a somewhat different faunal composition similar to the North-eastern communi- ty with Amphiura filiformis (102 ind $\left./ \mathrm{m}^{2}\right)$ and Bathyporeia elegans $\left(85 \mathrm{ind} / \mathrm{m}^{2}\right)$ as well as locally high abundances of Ophelia borealis $\left(58 \mathrm{ind} / \mathrm{m}^{2}\right)$ and Echinocyamus pusillus (199 ind $\left./ \mathrm{m}^{2}\right)$.

The trophic structure was as variable as the faunal composition. Due to the occurrence of Amphiura filiformis and Spiophanes bombyx, most stations were dominated by interface-feeding species. Sandlickers, represented by Bathyporeia elegans and Echinocyamus pusillus, were the dominant feeding types at the stations inhabited by the transitional community. Hyperbenthos predators such as Corymorpha nutans and Cerianthus lloydii occurred in varying numbers at both types of station.

\section{Correlations between feeding types and environmental variables}

Due to the high species numbers, and since the correlation of single species to the measured environmental variables was weak (Fig. 8), we correlated functional groups with environmental variables. Among the different feeding types only those species that forage in the sediment (sandlickers and subsurface deposit feeders) showed significant correlations with the measured environmental variables (Table 5). The abundance of sandlickers was negatively correlated with the fine fraction $(<63 \mu \mathrm{m}), \mathrm{TOC}_{\text {tot }}$, and $\mathrm{C} / \mathrm{N}_{\text {tot }}$, whereas their species number was correlated negatively with $\mathrm{TOC}_{\text {tot }}$ and positively with $\mathrm{TOC}_{<63 \mu \mathrm{m}}$.

Species numbers of subsurface deposit feeders were positively correlated with water depth and $\mathrm{C} / \mathrm{N}_{<63 u m}$ of the fine fraction, and negatively with $\mathrm{TOC}_{<63 \mu \mathrm{m}}$ and $\mathrm{N}_{<63 \mu \mathrm{m}}$. The abundance of subsurface deposit feeders was only correlated to water depth (positively). 
Table 5 Correlations between sediment and macrofauna; SL sandlickers, SSD subsurface deposit feeders; $* P<0.05, * * P<0.01$

\begin{tabular}{|c|c|c|c|c|c|c|c|c|}
\hline & Depth & $\begin{array}{l}\text { Fraction } \\
<63 \mu \mathrm{m}\end{array}$ & $\mathrm{TOC}_{\text {tot }}$ & $\mathrm{N}_{\text {tot }}$ & $\mathrm{C} / \mathrm{N}_{\text {tot }}$ & $\mathrm{TOC}_{<63 \mu \mathrm{m}}$ & $\mathrm{N}_{<63 \mu \mathrm{m}}$ & $\mathrm{C} / \mathrm{N}_{<63 \mu \mathrm{m}}$ \\
\hline $\begin{array}{l}\text { Total macrofauna abundance } \\
\text { Species number }\end{array}$ & & & & & & $*(+)$ & & \\
\hline Abundance SL & $* *(-)$ & $* *(-)$ & $* *(-)$ & $* *(-)$ & $* *(-)$ & & & \\
\hline Species number SL & $* *(-)$ & $* *(-)$ & $*(-)$ & $*(-)$ & $* *(-)$ & $*(+)$ & & \\
\hline $\begin{array}{l}\text { Abundance SSD } \\
\text { Species number SSD }\end{array}$ & $\begin{array}{l}* *(+) \\
* *(+)\end{array}$ & & & & & $*(-)$ & $* *(-)$ & $* *(+)$ \\
\hline
\end{tabular}

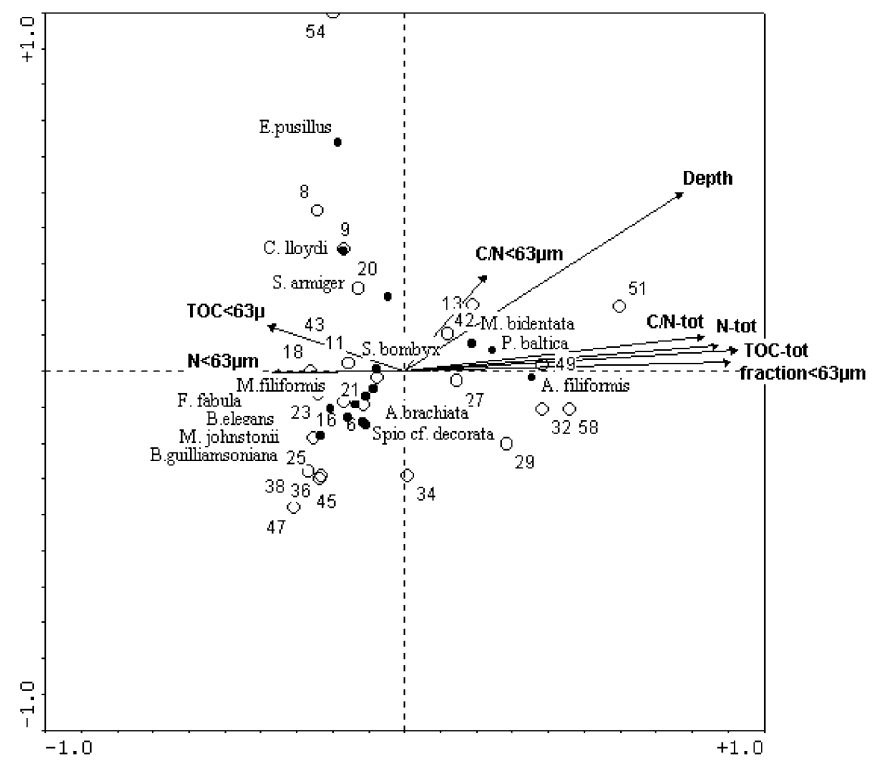

Fig. 8 Triplot of the CCA ordination of the species data from May 1996 only. Open circles represent the station positions within the ordination space, black dots represent the positions of individual taxa contributing significantly to the biological variance. The vector lines represent the relationship of significant environmental variables to the ordination axes, and their length is proportional to their relative significance

\section{Discussion}

The shallow parts (Bank community and South-West Patch)

The stations on top of the Dogger Bank were inhabited by a Bathyporeia-Fabulina community. Towards the southern slope, the abundance of Fabulina fabula, Amphiura brachiata and tube-building polychaetes such as Spiophanes bombyx and Owenia fusiformis increased.

The dominance of eurytherm cosmopolitan and temperate species such as Spiophanes bombyx and Bathyporeia elegans reflects the comparatively large seasonal variations in temperature in a shallow area such as the Dogger Bank (Künitzer 1990). However, high summer temperatures in connection with moderate winter temperatures (Otto et al. 1990) support the presence of southern species from warm temperate areas reaching the Dogger Bank via the English Channel (e.g. Megalur-

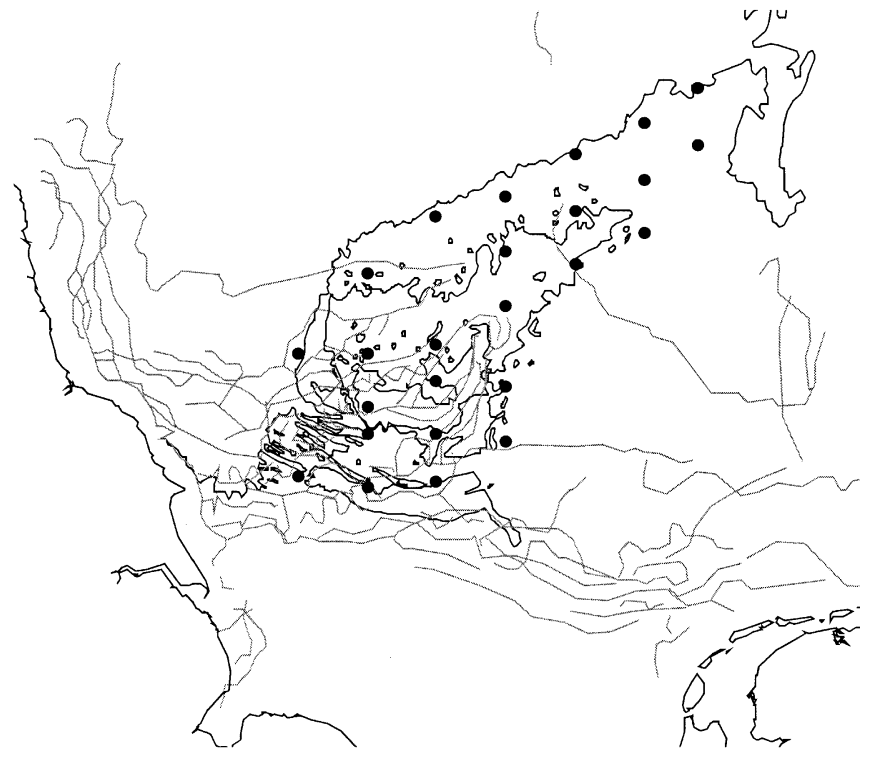

Fig. 9 Position of the Flamborough/Frisian frontal system (grey lines) from satellite infrared images in 1978-1980 (see Otto et al. 1990)

opus agilis, Amphiura brachiata, Donax vittatus, Synchelidium maculatum). Several species of this zoogeographical group actually increased in abundance and spread across the Dogger Bank as a result of temperature increase since the late 1980s (Wieking and Kröncke 2001).

The shallow part of the Dogger Bank is a highly dynamic area where periods of tidal resuspension and sedimentation alternate, but no net deposition occurs (von Haugwitz and Wong 1988; Puls 1987). As a result there is only minor accumulation of organic matter in the sediment (low $\mathrm{TOC}_{\text {tot }}$ ) and even in the surface layer, as measured by Stoeck and Kröncke (2001). There is no detailed information on sedimentation and resuspension on the Dogger Bank, but investigations on a sandy site in the southern North Sea inhabited by similar communities revealed that tidal resuspension potential is governed by the supply of benthic fluff (Jago and Jones 1998). Supply of fluff was greatest in May after phytoplankton blooms, but was still significant in January. The occurrence of thermal fronts might additionally support locally higher food supply to the benthos in the benthic boundary layer in several areas of the shallow part of the bank (Fig. 9) in 
addition to winter primary production. This is confirmed by the locally higher $\mathrm{TOC}_{<63 \mu \mathrm{m}}$ content of the fine fraction as well as the low $\mathrm{C} / \mathrm{N}$ ratios of TOC, indicating high quality of organic matter in the sediment. This input of little, but fresh, organic material in the shallow parts of the bank was also shown by Stoeck and Kröncke (2001) and Wieking (2002), using phytopigments as a marker for fresh organic material. This situation favours those species which feed in the benthic boundary layer, and especially those which are able to switch from surface deposit to suspension feeding. Indeed, interface feeding was the most important feeding type in the Bank community. The high quality of organic mater on top of the Dogger Bank was also reflected in the high quality of food in the gut of the surface-deposit-feeding sea urchin Echinocardium cordatum (Wieking and Kröncke 2002).

Sandlickers (such as Bathyporeia spp) were the second most important feeding type of the communities on top of the bank and even dominated the South-West Patch community (stations 45 and 47). The importance of species relying on the sediment as a food resource seems to contradict the finding of low amounts of food (as indicated by the low $\mathrm{TOC}_{\mathrm{tot}}$ ) in the sediments of the bank. But as already emphasized by Cammen (1982), "it would be difficult, if not useless, to attempt to assess nutritional quality of the sediment with bulk sediment analyses" for organisms that feed selectively on sediment and ingest only a limited range of particle sizes. Sandlicking species are highly selective deposit feeders. Bathyporeia spp. and cumaceans such as Iphinoe trispinosa are described as cleaning their food of sand grains. Sundbäck and Persson (1981) and Herman et al. (2000) showed that Bathyporeia pilosa, from coastal waters, feeds mainly on benthic diatoms. Taking the high abundances of amphipods into consideration, benthic primary production of small diatoms growing on sand grains seems to be an important food source in a shallow area with considerable light penetration, such as the Dogger Bank, as described for other shallow areas (Nelson et al. 1999; Cahoon et al. 1993).

At the exposed South-West Patch, the availability of rare and mainly small prey organisms is reflected in the presence of the small predatory polychaete Nephtys cirrosa, which replaces the bigger Nephtys hombergii and $N$. assimilis living in the other areas of the Dogger Bank. Gut contents of $N$. cirrosa from the South-West Patch stations consisted of up to $50 \%$ of juvenile $N$. cirrosa as well as small spionids, nematodes and harpacticoids (personal observations). This cannibalistic behaviour hints at a strong food limitation for this predatory polychaete, as well as the total community.

High abundance of mobile amphipods as well as tubebuilding polychaetes can be interpreted as an adaptation to sediment disturbances, such as mobilization of bed sediment during storms. The importance and frequency of sediment disturbance decreases with increasing depth (Hall 1994), which was reflected in an obvious change in species composition from mobile species at the more shallow sites towards a higher number of tube-building polychaetes at the deeper sites of the Bank community. Similar observations were made by Oliver et al. (1980) at a shallow sublittoral area at the Pacific coast off California. An additional hint for higher sediment mobility is the dominance of Amphiura brachiata in the Bank community. This buries deeper in the sediment than Amphiura filiformis, which is the dominant species of the deeper regions where sediment disturbance is less effective.

Even greater effects of hydrodynamic stress can be found at the South-West Patch sites. This shallow area on top of the Dogger Bank is strongly influenced by bottom stress and sediment disturbance during storm events (von Haugwitz and Wong 1988). The authors showed that during a north-westerly storm at a station on the South-West Patch, horizontal current speeds at $10 \mathrm{~m}$ depth exceeded $45 \mathrm{~cm} / \mathrm{s}$ for almost a day. Even the normal periodic tidal current became unidirectional. Frequent resuspension of bed sediment will erode organisms, inhibit larval settlement and damage the appendages of species feeding at the sediment-water interface (Dauwe et al. 1998). This strong environmental stress results in low abundance and a macrofauna community with low diversity, consisting of an adapted fauna such as the mobile amphipod Bathyporeia and the filter-feeding bivalve Donax vittatus, which is highly adapted to sediment mobility (Dörjes 1979; Ansell 1983).

\section{North-eastern transitional community}

The community in the northern and north-eastern part of the Dogger Bank (north-eastern community) was a transitional community similar to the Bathyporeia-Fabulina association on top of the Bank as well as to the Amphiura association described for the central North Sea by Duineveld et al. (1987) and Künitzer (1990). Amphiura filiformis appeared only at the deepest northern stations. In this community we found the highest species numbers, lowest total abundances and, consequently, highest diversity. On the other hand, it was characterized by higher numbers of rather rare northern species and species preferring coarser sediments (Wieking and Kröncke 2001). The occurrence of northern species reflects the influence of northern water masses and lower bottom temperatures on the species composition of this area.

The presence of species preferring coarser sediment indicates differences in the hydrodynamic conditions, and consequently in the food supply to the benthos, since sediment composition reflects the hydrodynamic regime in the benthic boundary layer. Moreover, passive penetration of organic matter into the sediment and, thus, food supply is strongly influenced by sediment composition (Huettel and Rusch 2000). For the north-eastern part of the Dogger Bank, only little and highly variable local sedimentation of refractory fine material of mainly biological origin occurred, reflected by the low $\mathrm{TOC}_{\text {tot }}$ content (generally below $0.1 \%$ ) and the high $\mathrm{TOC}_{<63 \mu \mathrm{m}}$ content (up to $3.5 \%$ ) and $\mathrm{C} / \mathrm{N}_{<63 \mu \mathrm{m}}$ ratio (7.5-9). At the cen- 
tral northern stations 21 and 42, both TOC parameters showed low values.

Macrofauna trophic structure indicated that the Northeastern community along the northern slope was influenced by low food quantities and quality (especially in the deeper parts) in the sediment as well as in the benthic boundary layer. Predators, hyperbenthos predators and symbiotic deposit feeders contributed to a high functional diversity along the northern slope, which is characteristic for communities in more refractory environments (Rosenberg et al. 1996; Dauwe et al. 1998). Subsurface deposit feeders (e.g. Pectinaria spp., Ampharete falcata, Paraonidae) and sandlickers such as Echinocyamus pusillus are highly selective, reflecting the low amount of food in the sediment (Taghon 1981, 1982). Low abundances of interface-feeding species indicate lower food quantity in the benthic boundary layer (Dauwe et al. 1998). Predatory behaviour is a possible mechanism to satisfy nutritional needs in refractory sediments (Dauwe et al. 1998). Consequently, the importance of hyperbenthos predators which fulfil their nutritional needs by predation in the water column or in the sediment might reflect nitrogen deficiencies in the pelagic-benthic coupling. Macrofauna abundances in the North-eastern community decreased towards the deeper northern stations and were correlated with $\mathrm{TOC}_{<63 \mu \mathrm{m}}$, which may indicate increasing food limitation of the macrobenthic community down the northern slope of the Dogger Bank.

Feeding modes, as well as sediment structure, reflect that the North-eastern community is heavily influenced by hydrodynamics. It is located in an area between the well-mixed water masses on top of the bank and the seasonally stratified water masses north of the bank. Where stratification occurs, the vertical exchange across the thermocline is considerably reduced (Otto et al. 1990), and consequently food quality can change substantially with developing stratification.

However, our data do not indicate any influence of subsurface phytoplankton production (up to $700 \mathrm{mg} \mathrm{C} / \mathrm{m}^{2}$ per day) as measured by Nielsen et al. (1993), which should result in additional food supply for the benthos. Stoeck and Kröncke (2001) have already suggested that microbial benthic communities do not benefit from the high primary production of the frontal system along the northern slope of the Dogger Bank (Bo Pedersen 1994; Riegmann et al. 1990; Nielsen et al. 1993; Richardson et al. 1998) due to strong hydrodynamic conditions. High current velocities in the north-eastern part of the Dogger Bank (Siegismund and Schrum 2001), in addition to a seasonal jet (Brown et al. 1999), limit the accumulation of particulate organic material in the sediment. In addition, Klein et al. (1999) showed that during storms fine sediment is mobilized up to $60 \mathrm{~m}$ depth at the northern slope of the Dogger Bank.

A model by Bo Pedersen (1994) described the northward transport of nutrient-rich deep water in the thermocline, which means that organic matter originating from the subsurface phytoplankton bloom might also be transported towards the central North Sea. Finally, the ob- served differences in the pelagic food web structure of the frontal system north of the Dogger Bank, compared with the surrounding waters (Richardson et al. 1998), showed that a significant part of the additional primary production is consumed in the pelagic system. As a consequence, the benthic system receives mainly refractory material, e.g. faecal pellets.

\section{The deeper parts (Southern and Western Amphiura communities)}

The southern and western Amphiura communities were similar as to the dominant species, but differed in the occurrence of species from the northern North Sea.

Species typical of cold temperate and Arctic boreal areas occurred mainly in the deeper part southwest of the Dogger Bank, reflecting the inflow of water masses from the north. A few species from warm temperate areas (Lumbrineris spp.) also occurred in these areas, possibly as a result of constant rather than high temperatures.

High fine fraction $\left(<63 \mu \mathrm{m}\right.$ ) (up to $13 \%$ ) and $\mathrm{TOC}_{\text {tot }}$ (up to $0.45 \%$ ) contents reflected sedimentation and accumulation of organic matter (Wirth and Wiesner 1988) in the south-western part of the Dogger Bank, but $\mathrm{TOC}_{<63 \mu \mathrm{m}}$ contents were low (1.9-2.8\%) and $\mathrm{C} / \mathrm{N}$ ratios high, indicating higher amounts of refractory organic matter.

The communities in the deeper south-western part of the Dogger Bank were (similarly to the Bank community) dominated by interface-feeding species foraging in the benthic boundary layer. The dominant species in the south-western part was Amphiura filiformis, an interface feeder ingesting both deposited and suspended food items, especially macro-flocs (Loo et al. 1996). The highest abundances of this species were also found in frontal areas such as the Skagerrak (Rosenberg 1995) and south of the Dogger Bank (Duineveld et al. 1987).

Thus, the extraordinarily high abundances of $A$. filiformis reveal that the communities of the deeper southern parts of the Dogger Bank were strongly dependent of lateral food supply provided by the Flamborough/Frisian frontal system, where favourable conditions for localized high primary production are generated (Fig. 9). This tidal front system is more stable than the northern bottom front (Otto et al. 1990; Hill et al. 1994). However, the nutritional value and composition of particulate organic matter produced in this area is altered during the transport through the water column as well as being diluted by mixing with large quantities of resuspended refractory material and inorganic particles at deeper water depths (Jones et al. 1998; Witbaard et al. 2001). Consequently, the material in the benthic boundary layer at these stations will be partly refractory and of intermediate quality (Puls 1987; Dauwe et al. 1998; Witbaard et al. 2001). This was confirmed by lower growth rates of the sea urchin Echinocardium cordatum in connection with lower food quality found in the sea urchin gut contents in this part of the Dogger Bank (Wieking and Kröncke 2002). 


\section{Conclusions}

According to the multivariate analysis, depth and sediment variables can explain part of the variability in species composition of the different macrofauna communities of the Dogger Bank, whereas sediment variables alone correlated only with a limited number of feeding types. Our detailed analysis of the different communities revealed that none of the measured variables per se is responsible for the observed differences among the macrofauna communities.

In the North Sea macrofauna, distribution and species composition often coincide with specific depth contours, indicating differences in temperature and temperature variability (Künitzer et al. 1992). However, although northern species occurred preferentially in the Northeastern community, all communities on the Dogger Bank were dominated by eurytherm temperate and cosmopolitan species. Consequently, differences in temperature were not the main factor causing the occurrence of different macrobenthic communities on the Dogger Bank. Moreover, lower temperatures at the northern slope are the effect of thermal stratification during summer, which in turn strongly influences the quality and quantity of food supply to the benthos.

Sediment variables only reflect the hydrodynamic conditions and thus, to some extent, food availability (Snelgrove and Butman 1994). During our large-scale investigations, food supply was only measured by means of TOC and TN, which are poor indicators for bioavailable organic matter and organic matter quality (Boon and Duineveld 1996, 1998; Dauwe et al. 1998). Bulk measurements of TOC and TN in sediments more often reflect refractory material which may be of little value for macrofauna (Rice 1982; Josefson and Conley 1997). Sediment bulk measures do not indicate differences in food availability for those species feeding selectively on a limited range of particles (Cammen 1982).

However, significant differences in the trophic structure of the communities suggest that the main factors causing the differences among the communities of the Dogger Bank were the availability, quantity and quality of food in the benthic boundary layer which, in turn, are partly dependent of frontal systems such as the Flamborough/Frisian frontal system. The importance of sandlickers in the shallowest parts of the Dogger Bank hints at a considerable contribution of benthic primary production to the nutritional and energetic needs of the benthic community on top of the bank.

Our results show that macrofaunal community structure and function are able to document and reflect pelago-benthic coupling in relation to hydrodynamics, since macrofauna integrates environmental conditions over longer time periods.

Acknowledgements Thanks are due to the Captain and crew of RV "Senckenberg". We thank our technical assistants, C. Rensing and T. Jansen, as well as many students for their help with sampling and sample analyses and S. Kusick for correcting the English.

\section{References}

Ansell AD (1983) The biology of the genus Donax. In: McLachlan A, Erasmus T (eds) Sandy beaches as ecosystems. Dev Hydrobiol 19:607-635

Bo Pedersen F (1994) The oceanographic and biological tidal cycle succession in shallow sea fronts in the North Sea and the English Channel. Estuar Coast Shelf Sci 38:249-269

Boon AR, Duineveld GCA (1996) Phytopigments and fatty acids as molecular markers for the quality of near-bottom particulate organic matter in the North Sea. J Sea Res 35:279-291

Boon AR, Duineveld GCA (1998) Chlorophyll a as a marker for bioturbation and carbon flux in southern and central North Sea sediments. Mar Ecol Prog Ser 162:33-43

Brown J, Hill AE, Fernand L, Horsburgh KJ (1999) Observations of a seasonal jet-like circulation at the Central North Sea cold pool margin. Estuar Coast Shelf Sci 48:343-355

Cahoon LB, Beretich GR Jr, Thomas CJ, McDonald AM (1993) Benthic microalgal production at Stellwagen Bank, Massachusetts Bay, USA. Mar Ecol Prog Ser 102:179-185

Cammen LM (1982) Effect of particle size on organic content and microbial abundance within four marine sediments. Mar Ecol Prog Ser 9:273-280

Dauwe B, Herman PMJ, Heip CHR (1998) Community structure and bioturbation potential of macrofauna at four North Sea stations with contrasting food supply. Mar Ecol Prog Ser 173: $67-83$

Davis FM (1923) Quantitative studies on the fauna of the sea bottom. 1. Fish Invest Ser II 6(2):1-54

Davis FM (1925) Quantitative studies on the fauna of the sea bottom. 2. Fish Invest Ser II 8(4):1-50

Dörjes J (1979) Zur Populationsdynamik des Sägezähnchens, Donax vittatus. Nat Mus 109:305-311

Duineveld GCA, Künitzer A, Heyman RP (1987) Amphiura filiformis (Ophiuroidea: Echinodermata) in the North Sea: distribution, present and former abundance and size composition. Neth J Sea Res 21:317-329

Eleftheriou A, Basford DJ (1983) The general behaviour and feeding of Cerianthus lloydi (Anthozoa, Coelenterata). Cah Biol Mar 24:147-158

Fauchald K, Jumars PA (1979) The diet of worms: a study of polychaete feeding guilds. Oceanogr Mar Biol Annu Rev 17:193-284

Hall SI (1994) Physical disturbance and marine benthic communities: life in unconsolidated sediment. Oceanogr Marine Biology Annu Rev 34:179-239

Hartmann-Schröder G (1996) Annelida, Borstenwürmer, Polychaeta. In: Dahl F (ed) Die Tierwelt Deutschlands und der angrenzenden Meeresteile. Fischer, Jena, Germany

Haugwitz W von, Wong HK (1988) The Dogger Bank: seismic stratigraphy and holocene sedimentation. In: Kempe S, Liebezeit G, Dethlefsen V, Harms U (eds) Biogeochemistry and distribution of suspended matter in the North Sea and implications to fisheries biology. (SCOPE/UNEP Sonderband 65) Geologisch-Paläeontologisches Institüt, Hamburg, pp 381-407

Hayward PJ, Ryland JS (1990) The marine fauna of the British Isles and North-West Europe. Clarendon, Oxford

Heip C, Basford D, Craeymeersch JA, Dewarumez JM, Dörjes J, Wilde $\mathrm{P}$ de, Duineveld $\mathrm{G}$, Eleftheriou A, Herman PMJ, Niermann U, Kingston P, Künitzer A, Rachor E, Rumohr H, Soetaert K, Soltwedel T (1992) Trends in biomass, density and diversity of North Sea macrofauna. ICES J Mar Sci 49:13-22

Herman PMJ, Middelburg JJ, Widdows J, Lucas CH, Heip CHR (2000) Stable isotopes as trophic tracers: combining field sampling and manipulative labelling of food resources for macrobenthos. Mar Ecol Prog Ser 204:79-92

Hill AE, James ID, Linden PF, Matthews JP, Prandle D, Simpson JH, Gmitrowicz EM, Smeed DA, Lwiza KMM, Durazo R, Fox AD, Bowers DG (1994) Dynamics of tidal mixing fronts in the North Sea. In: Charnock H, Dyer KR, Huthnance JM, Liss PS, Simpson JH, Tett PB (eds) Understanding the North Sea system. The Royal Society/Chapman and Hall, London, pp 53-68 
Holohan BA, Klos EG, Oviatt CA (1998) Population density, prey selection, and predator avoidance of the burrowing anemone (Ceriantheopsis americanus) in Narragansett Bay, Rhode Island. Estuaries 21:466-469

Huettel M, Rusch A (2000) Transport and degradation of plankton in permeable sediment. Limnol Oceanogr 45:534-549

Jago CF, Jones SE (1998) Observation and modelling of the dynamics of benthic fluff resuspended from a sandy bed in the southern North Sea. Cont Shelf Res 18:1255-1282

Jones SE, Jago CF, Bale AJ, Chapman D, Howland RJM, Jackson J (1998) Aggregation and resuspension of suspended particulate matter at a seasonally stratified site in the southern North Sea: physical and biological controls. Cont Shelf Res 18: 1283-1309

Josefson AB, Conley DJ (1997) Benthic response to a pelagic front. Mar Ecol Prog Ser 147:49-62

Kirkegaard JB (1969) A quantitative investigation of the central North Sea polychaeta. Spolia 29:1-285

Klein H, König P, Frohse A (1999) Currents and near-bottom suspended matter dynamics in the central North Sea during stormy weather: results of the PIPE '98 field experiment. Dtsch Hydrogr Z 51:1

Kröncke I (1990) Macrofauna standing stock of the Dogger Bank: a comparison. II. 1951-52 versus 1985-87: are changes in the community of the north-eastern part of the Dogger Bank due to environmental changes? Neth J Sea Res 25:189-198

Kröncke I (1991) The macrofauna distribution on the Dogger Bank in April/May 1985-87. Ber Biol Anst Helgol 8:1-137

Kröncke I (1992) Macrofauna standing stock of the Dogger Bank: a comparison. III. 1950-54 versus 1985-87: a final summary. Helgol Meeresunters 46:137-169

Kruskal JB, Wish M (1978) Multidimensional scaling. Sage, Beverly Hills, Calif.

Künitzer A (1990) A comparison of the Amphiura filiformis associations north-east of the Dogger Bank and of the German Bight. Neth J Sea Res 25:199-208

Künitzer A, Basford D, Craeymeersch IA, Dewarumez IM, Dörjes J, Duineveld GCA, Eleftheriou A, Heip C, Herman P, Kingston P, Niermann U, Rachor E, Rumohr H, Wilde PAI de (1992) The benthic fauna of the North Sea: species distribution and assemblages. ICES J Mar Sci 49:127-143

Lincoln RJ (1979) British marine Amphipoda: Gammaridea. Natural HIstory Museum, London

Loo L-O, Jonsson PR, Sköld M, Karlsson Ö (1996) Passive suspension feeding in Amphiura filiformis (Echinodermata: Ophiuroidea): feeding behaviour in flume flow and potential feeding rate of field populations. Mar Ecol Prog Ser 139:143-155

Nelson JR, Eckman JE, Robertson CY, Marinelli RL, Jahnke RA (1999) Benthic microalgal biomass and irradiance at the sea floor on the continental shelf of the South Atlantic Bight: spatial and temporal variability and storm effects. Cont Shelf Res 19:477-505

Nielsen TG, Lokkegard B, Richardson K, Bo Pedersen F, Hansen L (1993) Structure of plankton communities in the Dogger Bank area (North Sea) during a stratified situation. Mar Ecol Prog Ser 95:115-131

Oliver JS, Slattery PN, Hurlberg LW, Nybakken JW (1980) Relationships between wave disturbance and zonation of benthic invertebrate communities along a subtidal high-energy beach in Monterey Bay, California. Fish Bull USA 78:37-454

Otto L, Zimmermann ITF, Furnes GK, Mork M, Saetre R, Becker G (1990) Review of the physical oceanography of the North Sea. Neth J Sea Res 25:161-238

Petersen TH, Høpner (1977) The density, biomass and origin of the bivalves of the central North Sea. Medd Dan Fisk Havunders NS 7:221-273
Puls W (1987) Simulation of suspended sediment dispersion in the North Sea. ICES/CM, C37

Remane A (1940) Einführung in die zoologische Ökologie der Nord- und Ostsee. In: Grimpe G von, Wagler E (eds) Die Tierwelt der Nord- und Ostsee, vol I, part Ia. Akademische Verlagsgesellschaft, Leipzig, pp 1-238

Rice DL (1982) The detritus nitrogen problem: new observations and perspectives from organic geochemistry. Mar Ecol Prog Ser 9:153-162

Richardson K, Nielsen TG, Bo Pedersen F, Heilmann JP, Lokkegaard B, Kaas H (1998) Spatial heterogeneity in the structure of the planktonic food web in the North Sea. Mar Ecol Prog Ser 168:197-211

Riegman R, Malschaert H, Colijn F (1990) Primary production of phytoplankton at a frontal zone located at the northern slope of the Dogger Bank (North Sea). Mar Biol 105:329-336

Rosenberg R (1995) Benthic marine fauna structured by hydrodynamic processes and food availability. Neth J Sea Res 34: 303-317

Rosenberg R, Hellman B, Lundberg A (1996) Benthic macrofaunal community structure in the Norwegian trench, deep Skagerrak. J Sea Res 35:181-188

Siegismund F, Schrum C (2001) Decadal changes in wind forcing over the North Sea. Climate Res 18:39-45

Snelgrove PVR, Butman CA (1994) Animal-sediment relationships revisited: cause versus effect. Oceanogr Mar Biol Annu Rev 32:111-177

Stoeck T, Kröncke I (2001) Influence of particle mixing on vertical profiles of chlorophyll a and bacterial biomass in sediments of the German Bight, Oyster Ground and Dogger Bank (North Sea). Estuar Coast Shelf Sci 52:783-795

Sundbäck K, Persson L-E (1981) The effect of microbenthic grazing by an amphipod, Bathyporeia pilosa, Lindström. Kieler Meeresforsch 5:573-575

Taghon GL (1981) Beyond selection: optimal ingestion rate as a function of food value. Am Nat 118:202-214

Taghon GL (1982) Optimal foraging by deposit feeding invertebrates: roles of particle size and organic coating. Oecologia $52: 295-304$

Ursin E (1960) A quantitative investigation of the echinoderm fauna of the central North Sea. Medd Dan Fisk Havunders NS2 24:1-204

Wieking G (2002) The macrofauna at the Dogger Bank: food supply in relation to hydroclimate. $\mathrm{PhD}$ thesis. University of Oldenburg, Germany

Wieking G, Kröncke I (2001): Decadal changes in macrofaunal communities on the Dogger Bank caused by large-scale climate variability. In: Kröncke I, Türkay M, Sündermann J (eds) Burning issues of North Sea ecology: proceedings of the 14th international Senckenberg conference 'North Sea 2000'. Senckenbergiana marit 31:125-141

Wieking G, Kröncke I (2002) Abundance and growth of the sea urchin Echinocardium cordatum in the central North Sea in the late 80 s and 90 s. Senckenbergiana marit 32

Wirth H, Wiesner MG (1988) Sedimentary facies in the North Sea. In: Kempe S, Liebezeit G, Dethlefsen V, Harms U (eds) Biogeochemistry and distribution of suspended matter in the North Sea and implications to fisheries biology. (SCOPE/UNEP Sonderband 65) Geologisch-Paläeontologisches Institüt, Hamburg, pp 289-311

Witbaard R, Duineveld GCA, Bergman M (2001) Food supply to the benthos: do qualitative characters determine growth? In: Kröncke I, Türkay M, Sündermann J (eds) Burning issues of North Sea ecology: proceedings of the 14th international Senckenberg conference 'North Sea 2000'. Senckenbergiana marit 31:225-234 